\title{
Publication of a Special Issue: Gene Dosage Effect During Embryonic Development
}

\author{
Claire Redhead \\ TheScientificWorld \\ E-mail: credhead@thescientificworld.com
}

Published June 12, 2007

TheScientificWorldJOURNAL and TSW Development \& Embryology are pleased to have published the special issue 'Gene Dosage Effect During Embryonic Development', a collection of peer-reviewed papers on a range of key topics in this field. The issue has been organized by Dr. Yann Hérault (Group Leader, Molecular Embryology and Morphogenesis, CNRS, France) and specific topics covered are:

- The 22q11.2 Deletion Syndrome: A gene dosage perspective

- DYRK1A (dual-specificity tyrosine-phosphorylated and regulated kinase 1A): a gene with dosage effect during development and neurogenesis

- Developmental defects in trisomy 21 and mouse models

- The William Beuren Syndrome

- Transcriptional consequences of gene dosage imbalance on cerebellum development

The Publisher wishes to thank the authors and reviewers, and especially acknowledges the contribution of Dr. Hérault in bringing about the publication of this special issue. 

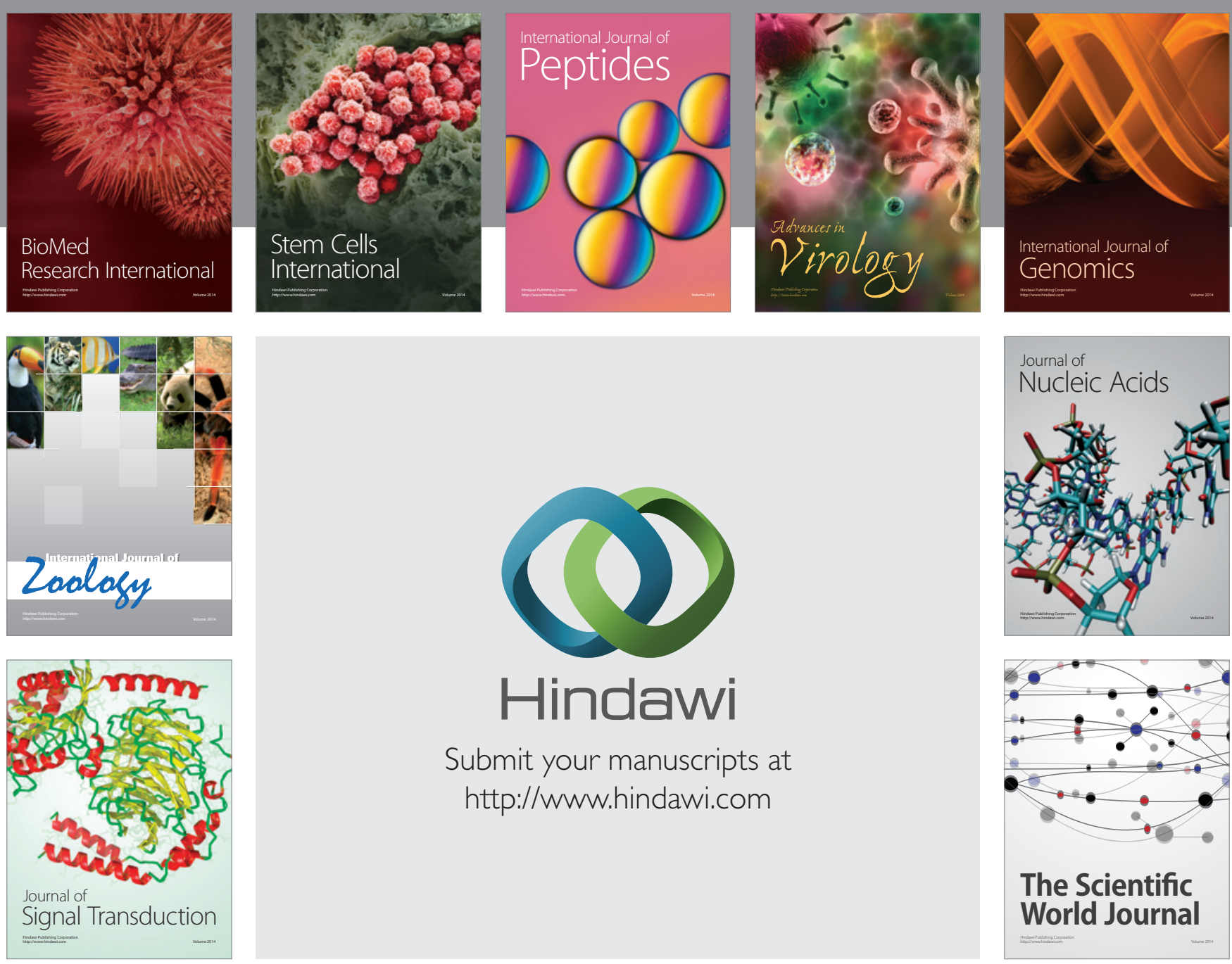

Submit your manuscripts at

http://www.hindawi.com
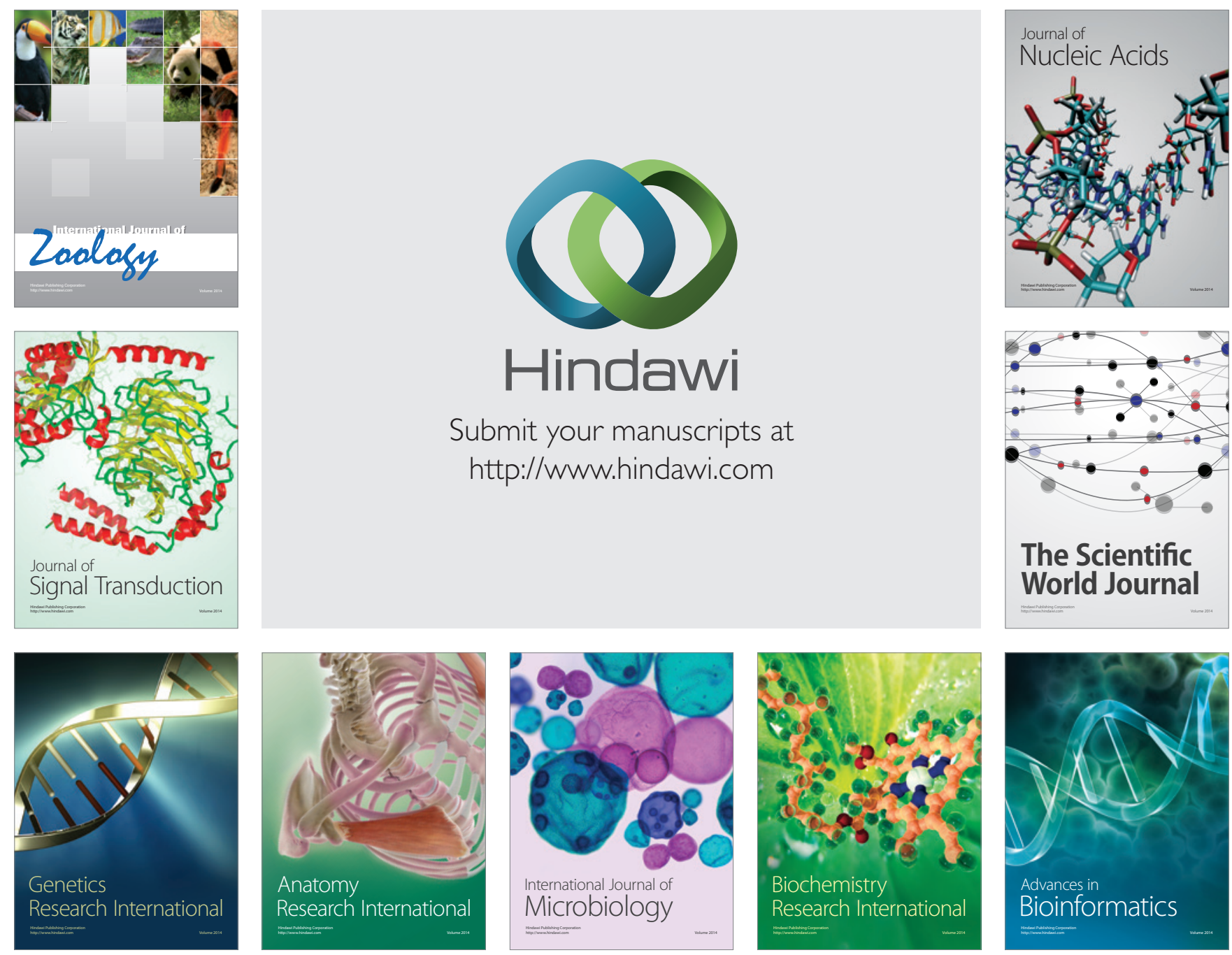

The Scientific World Journal
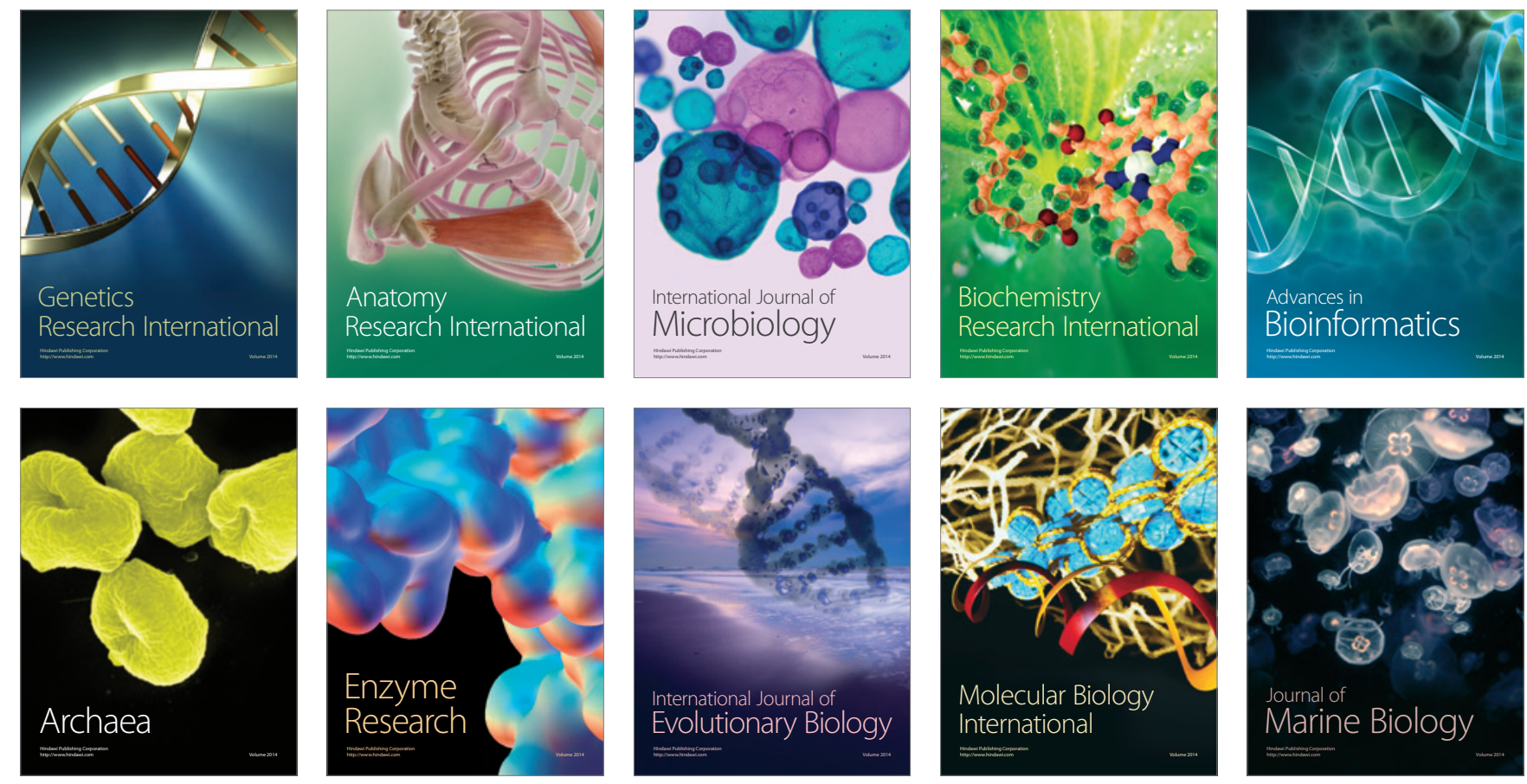